\title{
The analysis of the genus Rosa L. in the flora of Dagestan
}

\author{
Bayzanat Ramazanova*, Maxim Mallaliev, and Gulnara Sadykova
}

The Mountain Botanical Garden of the Dagestan Federal Scientific Centre of the Russian Academy of Sciences, 367000, 75 Yaragskogo str., Machachkala, Russian Federation

\begin{abstract}
The given article dwells upon the floristic composition of the wild roses in Dagestan which includes 46 species. The species composition of roses of Dagestan has not been sufficiently researched and requires a more serious and detailed approach. The aim of the given work is the inventory of the flora of the wild roses of Dagestan. Stemming from this, the following tasks are being solved: specification of the species composition and geographic dissemination of the species of the genus Rosa L. in Dagestan. In sum, the taxonomic composition of the genus Rosa in Dagestan is not homogeneous. Within it there can be definitely singled out large species characterized by wide distribution and close concordance with the diagnoses of descriptions. These are the species $R$. canina L., $R$. corymbifera Borkh., $R$. pimpinellifolia $\mathrm{L}$., $R$. oxyodon Boiss.. All of them possess high polymorphism and for these species there has been pointed out a great number of forms with different variations of signs. The second group is composed of the species with smaller natural habitats, and they are usually less changeable. It has been established that the leading geoelements are the Caucasian and Dagestani ones. A high percentage of the endemic species testifies to the fact that the examined area, as well as the Caucasus in general, is the centre of intensive speciation.
\end{abstract}

\section{Introduction}

The first data on wild roses in Dagestan can be found in the works of M. Bieberstein. In 1872 E. Boissier, based on the collections of F.J. Ruprecht, cited 9 species and 3 varieties in reference to Dagestan: $R$. pimpinellifolia var. tomentella Boiss., $R$. oplisthes Boiss., $R$. tuschetica Boiss., $R$. oxyodon var. pleiantha Boiss., R. pomifera Herrm., R. ruprechti var. daghestanica Boiss., R. hamaetodes Boiss., R. didoensis Boiss., R. canina L. [1]. Later on, the data on the species composition of wild roses in Dagestan were published in the works of F.I. Schmalhausen and V.I. Lipsky. In sum, by the beginning of the $20^{\text {th }}$ century different researchers had cited 16 species, 5 varieties and 1 form of a rose [2]:

$R$. pimpinellifolia $\mathrm{L}$.

$R$. pimpinellifolia var. myriacantha $\mathrm{DC}$.

$R$. pimpinellifolia var. elasmacantha Trautv.

f. typica Schmalh.

* Corresponding author: baizana@mail.ru 
R. tuschetica Boiss.

$R$. oxyodon Boiss.

$R$. oxyodon var. pleiantha Boiss.

$R$. oplisthes Boiss.

R. pomifera Herrm.

$R$. ruprechti Boiss.

$R$. ruprechti var. daghestanica Boiss.

$R$. hamaetodes Boiss.

$R$. didoensis Boiss.

$R$. glutinosa Smith

R. leucantha Bieb.

R. iberica Stev.ex Bieb.

$R$. boissieri Crep.

R. tomentosa Smith

R. cuspidata Bieb.

$R$. dumetorum Thuill.

$R$. canina $\mathrm{L}$.

$R$. canina var. hyspida Schmalh.

S.V. Yuzepchuk pointed out 13 species on the territory of Dagestan in his work "Flora of the U.S.S.R." [3]. Later on, S.G. Tamamshyan [4] and A.A. Grossheim [5] dedicated their works to the roses of the Caucasus in general and Dagestan, in particular. In 1958 there was published a research by V.G. Khrzhanovsky [6] which was a revision of the species Rosa in the European part of the former USSR and the Caucasus. The author cited 16 species and 3 varieties in reference to the territory of Dagestan.

In the following years the roses of the Caucasus were described in the works of A.I. Galushko [7, 8, 9]. In 1985 in the work "Roses of Dagestan' E.S. Kolobov [2] cited 31 species and 4 varieties in reference to Dagestan: $R$. canina L. ( $R$. canina var didoensis (Boiss.) Grossh., R. canina var. hispida Schmalh.), R. corymbifera Borkh. (R. corymbifera var. setoso-pedicellata Chrshan.), $R$. teberdensis Chrshan., $R$. pomifera Herrm., $R$. ruprechtii Boiss., $R$. brotherorum Chrshan., $R$. svanetica Crep., $R$. galuschkoi Demirova, $R$. tomentosa Smith, $R$. prilipkoana Sosn., $R$. boissieri Crep., $R$. cuneicarpa Galushko et Bagath., R. komarovii Sosn., R. obtusifolia Desvaux, $R$. tuschetica Boiss., $R$. pulverulenta Bieb., R. azerbaidschanica Novopork. et Rza-zade, R. nisami Sosn., R. sachokiana P. Jarosch., $R$. danaiorum Bagath., $R$. marschalliana Sosn., $R$. zangezura P. Jarosch., $R$. iberica Stev., $R$. oxyodon Boiss., $R$. sosnovskyana Tamamsch., $R$. prokhanovii Galushko, $R$. glabrifolia C.A.Mey. ex Rupr., $R$. buschiana Chrshan., $R$. spinisissima L., R. elasmacantha Trautv. (R. elasmacantha var. elasmacantha Shmalh.), R. tschatyrdagi Chrshan.

Nevertheless, despite the valuable data offered by the aforementioned researchers, the species composition of roses of Dagestan has not been sufficiently researched and requires a more serious and detailed approach.

The aim of the given work is the inventory of the flora of the wild roses of Dagestan. Stemming from this, the following tasks are being solved: specification of the species composition and geographic dissemination of the species of the genus Rosa L. in Dagestan.

\section{Methods}

To meet these challenges a routing method of the study of the territory with the description of the characteristics of the bushes or clumps has been applied. There have been registered the general sizes of the plant and peculiarities which are hard to reflect in the herbarium. A number was attrbuted to each object, several digital photos were taken and herbarium specimen with the fruits were selected (1-4 herbarium sheets). 
Later on, an office processing of herbarium sheets was performed. The material for the research was gathered along the rivers Avarsk-Koisu, Andis-Koisu and Samur. In the course of the conducted research 140 specimen were studied.

\section{Results}

According to the "Summary of the flora of Dagestan" [10], there are 46 species on the examined territory (Table 1). The species composition of the genus Rosa in Dagestan belongs to four sections: Gallicanae DC, Pimpinellifoliae DC, Cinnamomea DC, Caninae DC. The section Gallicanae is represented by one species, $R$. gallica L., which in reference to Dagestan is indicated in the suburbs of Derbent. A.A. Grossheim [5] cites this species of Dagestan as a cultivated plant. $R$. gallica is the most ancient species out of the modern roses in the Caucasus. The current species has not been found in the course of large-scale expeditions carried out by the researchers from the Mountain Botanical Garden of the Dagestan Federal Scientific Centre of the Russian Academy of Sciences.

The section Pimpinellifoliae has been represented by 4 species: $R$. pimpinellifolia L., $R$. elasmacantha Trautv., $R$. myriacantha DC. ex Lam., $R$. tschatyrdagi Chrishan. The species of this section are encountered in Intramountain Dagestan, especially in the limestone area. They are characteristic of upland xerophyte aggregations and occur on shallow rubbly soil and stony slopes [1]. The most widespread species of this section is $R$. pimpinellifolia. It appeared in the Pleistocene and it presently occupies a vast area from the Pacific up to the Atlantic Ocean. R. pimpinellifolia is a highly polymorphic species $[6,2,11,12]$ which is characterised by the appearance of various forms that are markedly different from each other according to their morphological signs. A congenial species $R$. elasmacantha refers to Caucasian endemics and provenly occurs in Kabardino-Balkaria, the Chechen Republic, Karachay-Cherkessia, North Ossetia-Alania and Dagestan.

Nevertheless, for a certain while the mere existence of this species had been questioned as no one collected $R$. elasmacantha in the Caucasus after the description of S.V. Yuzepchuk [5] and V.G. Khrzhanovsky [6].

$R$. myriacantha is quite a widespread species which differs from $R$. pimpinellifolia by the double glandulous serrate leaves with the presence of glandules on the underside of the leaf.

Some researchers $[5,6]$ do not recognize $R$. myriacantha as a species, but consider it a variety of $R$. spinosissima ( $R$. pimpinellifolia) v. myriacantha DC. R. tschatyrdagi was first cited under the name R. myriacantha by M. Bieberstein in the Crimea. Later on, he came to a conclusion that is was a new species. That opinion was shared by S.V. Yuzepchuk [5], but M. Biebertsein did not diagnose a new species.

V.G. Khrzhanovsky [6] described $R$. tschatyrdagi as a species and underlined its significant changeability.

The section Cinnamomea DC is represented by 4 species: $R$. glabrifolia C. A. Mey ex Rupr., R. oxyodon Boiss., R. prokhanovii Galushko, R. sosnovskyana Tamamsch. By its nature this section is a mountain one, it occurs in middle and upper mountain belts. These sections are attributed to the mesophilous phytocenoses on the thick and moderately developed soils [1].

I.O. Buzunova and R.V. Kamelin [13] argue that the species $R$. oxyodon, $R$. prokhanovii, $R$. sosnovskyana constitute an ancient group of species of affinity $R$. oxyodon Boiss. s.l. Nevertheless, personal research of the morphological signs of the aforementioned species and the polymorphism analysis of 115 ISSR markers does not warrant their singling out as independent species [1]. According to the received data, $R$. oxyodon is a unified polymorphic species which is sufficiently widely represented in the Caucasus. 
R. glabrifolia is related to the species of the affinity $R$. majalis Herrm s. 1. This species was cited for the first time in reference to Dagestan by E.S. Kolobov [2]. Nowadays a number of researchers such as I.A. Shantser, G.Y. Klinkova [14], I.A. Shantser, V.N. Voylokova [15] consider $R$. glabrifolia in the frame of the species $R$. majais. The latter, as a highly polymorphic species, presents a complex of species $R$. majalis s. str., $R$. glabrifolia, $R$. gorinkensis, $R$. pratorum $[14,17,18]$.

The section Caninae DC is represented by 32 species: $R$. afzeliana Fries, $R$. azerbaidschanica Novopork. et Rza-zade, $R$. awarica Gussejnov, $R$. balsamica Bess., $R$. boissieri Crep., $R$. brotherorum Chrschan., $R$. buschiana Chrschan., $R$. canina L., $R$. corymbifera Borkh., $R$. cuneicarpa Galushko et Bagath., $R$. danaiorum Bagath., $R$. darginica Gussejnov, $R$. didoensis Boiss., $R$. galuschkoi Demurova, $R$. iberica Stev., $R$. kamelinii Gussejnov, $R$. komarovii Sosn., $R$. marschalliana Sosn., $R$. micrantha Borrer ex Smith, $R$. mollis Smith, $R$. nisami Sosn., R. oplisthes Boiss., R. prilipkoana Sosn., $R$. pulverulenta Bieb., $R$. sachokiana P. Jarosch, $R$. subbuschiana Gussejnov, $R$. svanetica Crep., $R$. teberdensis Chrschan., $R$. tlaratensis Gussejnov, $R$. tomentosa Smith, $R$. tuschetica Boiss., $R$. irinae Demurova ( $R$. usischensis Gussejnov), $R$. villosa L., $R$. zangezura P. Jarosch. This is one of the most difficult groups for research as it is characterized by a high polymorphism $[6,2,13,19,20,21]$. Its representatives are widespread in all parts of Dagestan: Lower, Foothill, Intramountain and partly in Highmountain Dagestan.

The representatives of this subsection occur among the mesophyte dumetosous formations; among the alpine and subalpine grasslands, as well as on the stony substrates and in the petrous upland habitats. The most widespread representative of this section $R$. canina is highly changeable and forms highly localized forms of various degrees of isolation $[5,6,2]$. The closest to $R$. canina is the species $R$. corymbifera the geographic dissemination of which coincides with the aforenamed species.

The researchers of the institute have revealed a great part of the flora of wild roses of Dagestan in the course of the expedition (Table 1). At the same time, we have discovered the species which were close to the diagnoses which had already been known, but which had not been mentioned in the "Summary of the flora of Dagestan" [10]. Nowadays the herbarium of the institute includes some specimen the identification of which is complicated. A number of them approximates by the aggregate of signs to the already known species which were not mentioned in regard to the territory of Dagestan. Other specimen diverge from the known diagnoses.

Table 1. The species composition of Rosa in the flora of Dagestan.

\begin{tabular}{|c|l|c|c|}
\hline \multicolumn{1}{|c|}{ Genus Rosa } & $\begin{array}{c}\text { Summary } \\
\text { of the flora } \\
\text { of Dagestan }\end{array}$ & $\begin{array}{c}\text { Personal } \\
\text { collections }\end{array}$ \\
\hline \multicolumn{3}{|c|}{ Sectio 1. Caninae DC. } \\
\hline 1. & R. afzeliana Fries & + & + \\
\hline 2. & R. azerbaidschanica Novopork. et Rza-zade & + & + \\
\hline 3. & R. awarica Gussejnov & + & - \\
\hline 4. & R. balsamica Bess. & + & - \\
\hline 5. & R. boissieri Crep. & + & - \\
\hline 6. & R. brotherorum Chrshan. & + & - \\
\hline 7. & R. buschiana Chrshan. & + & + \\
\hline 8. & R. canina L. & + & + \\
\hline 9. & R. corymbifera Borkh. & + & + \\
\hline 10. & R. cuneicarpa Galushko et Bagath. & + & + \\
\hline 11. & R. danaiorum Bagath. & + \\
\hline
\end{tabular}




\begin{tabular}{|c|c|c|c|}
\hline 12. & $R$. darginica Gussejnov & + & - \\
\hline 13. & $R$. didoensis Boiss. & + & + \\
\hline 14. & R. galuschkoi Demurova & + & + \\
\hline 15. & R. iberica Stev. & + & + \\
\hline 16. & R. balsamica Bess. & + & - \\
\hline 17. & R. kamelinii Gussejnov & + & - \\
\hline 18. & R. komarovii Sosn. & + & + \\
\hline 19. & R. marschalliana Sosn. & + & + \\
\hline 20. & R. micrantha Borrer ex Smith & + & + \\
\hline 21. & R. mollis Smith & + & - \\
\hline 22. & R. nisami Sosn. & + & + \\
\hline 23. & R. oplisthes Boiss. & + & + \\
\hline 24. & R. prilipkoana Sosn. & + & - \\
\hline 25. & R. pulverulenta Bieb. & + & + \\
\hline 26. & R. sachokiana P. Jarosch & + & + \\
\hline 27. & R. subbuschiana Gussejnov & + & - \\
\hline 28. & R. svanetica Crep. & + & + \\
\hline 29. & R. teberdensis Chrshan. & + & + \\
\hline 30. & R. tlaratensis Gussejnov & + & - \\
\hline 31. & R. tomentosa Smith & + & - \\
\hline 32. & R. tuschetica Boiss. & + & + \\
\hline 33. & $\begin{array}{l}R \text {. irinae Demurova (R. usischensis } \\
\text { Gussejnov) }\end{array}$ & + & - \\
\hline 34. & R. villosa $\mathrm{L}$ & + & + \\
\hline 35. & R. zangezura P. Jarosch. & + & + \\
\hline \multicolumn{4}{|c|}{ Sectio 2. Cinnamomeae DC. } \\
\hline 36. & R. glabrifolia C.A.Mey.ex Rupr. & + & + \\
\hline 37. & R. oxyodon Boiss. & + & + \\
\hline 38. & R. prokhanovii Galushko & + & + \\
\hline 39. & R. sosnovskyana Tamamsch. & + & + \\
\hline \multicolumn{4}{|c|}{ Sectio 3. Pimpinellifoliae DC. } \\
\hline 40. & R. elasmacantha Trautv. & + & + \\
\hline 41. & R. myriacantha DC. ex Lam. & + & + \\
\hline 42. & R. pimpinellifolia $\mathrm{L}$ & + & + \\
\hline 43. & R. tschatyrdagi Chrishan. & + & - \\
\hline \multicolumn{4}{|c|}{ Sectio 4. Gallicanae DC. } \\
\hline 44. & R. gallica L. & + & - \\
\hline \multicolumn{4}{|c|}{ Unclear state } \\
\hline 45. & R. altidaghestanica Gussejnov & + & - \\
\hline 46. & R. cziragensis Gussejnov & + & - \\
\hline 47. & R. pseudovalentinae Bagath. & + & + \\
\hline
\end{tabular}

The analysis of the floristic composition of the roses of Dagestan allows us to single out 16 geographic elements which confirm the idea of the contacts with the adjacent territories (Table 2). Based on the number of species and percentage participation, the most prevalent group is the group of geoelements of the Caucasian type of natural habitats which includes 28 species that constitute $59,5 \%$ of the whole composition of the roses in Dagestan (Table 2). Almost all the species constituting the group of elements of the caucasian type are endemics. Out of them dagestani endemics make up $21,3 \%$ of the whole spectrum of wild roses. The second place is occupied by the geoelements of boreal type $(23,3 \%)$ among which european elements prevail. The third place is occupied by the group of elements of 
xerophyte type $(14,8 \%)$ which is represented by the mediterranean ( $R$. micrantha), eastern mediterranean ( $R$. pulverulenta), Asia Minor Caucasian $(R$. boissieri, $R$. iberica, $R$. svanetica), atropotan ( $R$. zangezura) and northern atropotan ( $R$. sosnovskyana) geoelements. The lowest percentage is the steppe type of natural habitats $(2,1 \%)$ represented by one subpontian geoelement (R. tschatyrdagi).

Table 2. The ratio of botanico-geographical elements of the flora of Rosa L. in Dagestan.

\begin{tabular}{|c|c|c|c|}
\hline Type of zone & $\begin{array}{c}\text { Geoelements } \\
\text { according to A.A. } \\
\text { Grosheim (1935) }\end{array}$ & Species & $\%$ \\
\hline \multirow{4}{*}{ boreal } & western palearctic & R. canina, R. glabrifolia & 4,2 \\
\hline & southern palearctic & R. pimpinellifolia & 2,1 \\
\hline & european & $\begin{array}{l}\text { R. corymbifera, } R . \\
\text { afzeliana, } R . \text { mollis, } R . \\
\text { tomentosa, } R . \text { gallica }\end{array}$ & 10,6 \\
\hline & euro-caucasian & $\begin{array}{l}R . \text { balsamica, } R . \text { villosa, } R \text {. } \\
\text { myriacantha }\end{array}$ & 6,4 \\
\hline steppe & subpontian & R. tschtyrdagi & 2,1 \\
\hline \multirow{5}{*}{ xerophilous } & mediterranean & R. micrantha & 2,1 \\
\hline & eastern mediterranean & R. pulverulenta & 2,1 \\
\hline & asia minor caucasian & $\begin{array}{l}\text { R. boissieri, R. iberica, } R \text {. } \\
\text { svanetica }\end{array}$ & 6,4 \\
\hline & atropotan & R. zanzegura & 2,1 \\
\hline & northern atropotan & R. sosnovskyana & 2,1 \\
\hline \multirow{6}{*}{ caucasian } & caucasian & $\begin{array}{l}\text { R. azerbaidschanica, } R . \\
\text { brotherorum, } R . \text { danaiorum, } \\
R . \text { galushkoi, } R . \text { nisami, } R . \\
\text { teberdensis, } R . \text { tuschetica, } \\
R . \text { oxyodon, } R . \text { buschiana, } \\
R . \text { prokhanovii, } R . \\
\text { elasmacantha, } R . \\
\text { prilipkoana, } R . \\
\text { pseudovalentinae }\end{array}$ & 29,8 \\
\hline & eastern caucasian & R. komarovii & 2,1 \\
\hline & evcaucasian & R. marschalliana & 2,1 \\
\hline & eucaucasian & R. oplisthes & 2,1 \\
\hline & dagestani & $\begin{array}{l}\text { R. cuneicarpa, } R \text {. didoensis, } \\
\text { R. awarica, } R \text {. darginica, } R \text {. } \\
\text { kamelinii, } R \text {. usischensis, } R \text {. } \\
\text { altidagestanica, } R \text {. } \\
\text { cziragensis, } R . \\
\text { subbuschiana, } R . \\
\text { tlaratensis, }\end{array}$ & 21,3 \\
\hline & albanian & R. sachokiana & 2,1 \\
\hline
\end{tabular}

Nowadays there have been singled out 13 floristic zones in Dagestan based on the endemism and geobotanical peculiarities: Coastal, Tersko-Kumsky (Ter.-Kum.), TerskoSulaksky (Ter.-Sul.), Kazbekovsky (Kazb.), Primorsky (Primor.), Buynaksky (Buyn.), Kaitagsko-Tabasaransky (Kayt.-Tab.), Samursky (Sam.), Central Dagestani (Cent. Dag), 
Akhtinsko-Kurinsky (Akht.-Kur.), Diklosmto-Dultydagsky (Dik.-Dult.), BezhtinskoDidoysky (Bezht.-Did., Trans-Samur [17, 10]. The data in the table show the distribution of geoelements in the frame of these districts.

The widest species in terms of natural habitats are the species of the boreal group which are practically represented in 10 floristic districts. At the same time, the main species diversity is attributed to Intramountain and High-mountain Dagestan. The xerophyte and Caucasian type of natural habitats are quite widely represented in 7 and 8 floristic districts in accordance with the main diversity in the mountainous part of Dagestan. The steppe type of natural habitats has the lowest distribution rate (in 4 floristic zones).

Table 3. Distribution of geographic elements of the flora of wild roses in Dagestan within the limits of its floristic zones.

\begin{tabular}{|c|c|c|c|c|c|c|c|c|c|c|c|c|c|c|}
\hline \multirow[b]{2}{*}{$\begin{array}{l}\text { Zone } \\
\text { type }\end{array}$} & \multirow[b]{2}{*}{$\begin{array}{c}\text { Geographi } \\
\text { c elements } \\
\text { of flora }\end{array}$} & \multicolumn{13}{|c|}{ Floristic zones/ number of species } \\
\hline & & 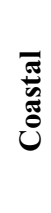 & 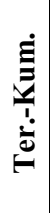 & $\begin{array}{l}\dot{\bar{\Xi}} \\
\underline{0} \\
\dot{0} \\
\dot{0}\end{array}$ & $\begin{array}{l}\dot{\hat{N}} \\
\text { Vี }\end{array}$ & 苛 & $\dot{\bar{\Xi}}$ & 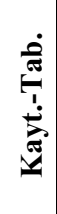 & 鸹 & 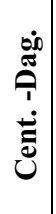 & 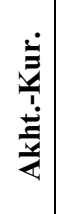 & 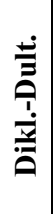 & 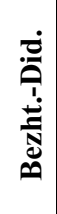 & 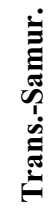 \\
\hline \multirow{4}{*}{ Boreal } & $\begin{array}{l}\text { western } \\
\text { palearctic }\end{array}$ & - & - & - & 1 & 1 & 1 & 1 & - & - & 2 & - & - & - \\
\hline & $\begin{array}{l}\text { southern } \\
\text { palearctic }\end{array}$ & - & - & - & - & - & - & - & - & 1 & 1 & 1 & 1 & 1 \\
\hline & european & - & - & 1 & 1 & 4 & 1 & 1 & 2 & 3 & 3 & 2 & 1 & - \\
\hline & $\begin{array}{l}\text { euro- } \\
\text { caucasian }\end{array}$ & - & - & - & - & 1 & - & - & - & 2 & 3 & 2 & 2 & 1 \\
\hline Steppe & subpontian & - & - & 1 & - & 1 & 1 & - & - & - & 1 & - & - & - \\
\hline \multirow{5}{*}{$\begin{array}{l}\text { Xerophilo } \\
\text { us }\end{array}$} & $\begin{array}{l}\text { mediterrane } \\
\text { an }\end{array}$ & - & - & - & - & 1 & - & - & - & 1 & 1 & - & 1 & - \\
\hline & $\begin{array}{l}\text { eastern } \\
\text { mediterrane } \\
\text { an }\end{array}$ & - & - & - & - & - & - & - & - & 1 & 1 & - & - & - \\
\hline & $\begin{array}{l}\text { asia minor } \\
\text { caucasian }\end{array}$ & - & - & - & 1 & 2 & - & - & - & 2 & 3 & 2 & 1 & 2 \\
\hline & antropotan & - & - & - & - & - & - & - & - & 1 & - & 1 & - & - \\
\hline & $\begin{array}{l}\text { northern } \\
\text { antropotan }\end{array}$ & - & - & - & - & - & - & - & - & - & - & 1 & - & - \\
\hline \multirow{6}{*}{ Caucasian } & caucasian & - & - & - & - & 2 & 1 & 3 & 1 & 6 & 8 & 6 & 2 & - \\
\hline & $\begin{array}{l}\text { eastern } \\
\text { caucasian }\end{array}$ & - & - & - & - & 1 & 1 & - & - & - & 1 & - & - & 1 \\
\hline & evcaucasian & - & - & - & - & 1 & - & - & - & - & - & - & - & - \\
\hline & eucaucasian & - & - & - & - & - & - & - & - & 1 & 1 & 1 & - & - \\
\hline & dagestani & - & - & - & - & - & 1 & 1 & - & 5 & 3 & 4 & 3 & - \\
\hline & albanian & - & - & - & - & - & - & 1 & - & 1 & 1 & - & 1 & - \\
\hline
\end{tabular}

Wild roses grow practically in all areas of Dagestan, in all its physiographic zones: Lower, Foothill, Intramouintain and High-mountain. They essentially tend to occur in two zones: Intramouintain Dagestan and High-mountain Dagestan. Less frequent is their occurrence in Foothill Dagestan (mainly the representatives of the section Caninae). As for 
Lower Dagestan, wild roses sporadically grow mainly in the deltas of the rivers Sulak, Samur and Terek.

\section{Discussion}

Thus, the flora of wild roses in Dagestan is a conglomeration of species varying in terms of their origin. The prevailing geoelements form the following row based on the influence on the formation of the general flora spectrum of wild roses: Caucasian - boreal - xerophilous - steppe. Its core is formed by the Caucasian and Dagestani species. A high percentage of endemic species points to the fact that the examined region, as well as the Caucasus in general, is the centre of intensive speciation. It becomes clear if one takes into account the fact that the flora of Dagestan began to develop in the Tertiary period when, as a result of orogeny in the Tethys ocean, there appeared the Caucasian island [23-26]. A high percentage of the roses of boreal type can be explained by the ancient nature of the genus Rosa. As was pointed out by A.A. Fyodorov [24], the boreal influence in regard to the flora of the Caucasus must be attributed to the Pliocene period, and the appearance of 'boreal' species in the Caucasian forests is explained by the fact that by that period of glaciation there had increased the number of specimens of these species which had themselves originated from the bosom of tertiary flora. The geoelements of the xerophyte type constitute $14,8 \%$, although, taken within the limits of the entire Caucasus, their share amounts to the half of all the species of the flora [27]. The lowest percentage rate is the steppe type of natural habitats represented by one geoelement ( $R$. tschatyrdagi). It coincides with the general tendency in the Caucasus as a whole [27].

The received data demonstrate that Caucasian species prevail in the spectrum of geoelements of the genus Rosa (59,5\%). The isolating of endemics, as can be seen from the data given earlier, was realized mainly on the basis of the species of the sections Caninae и Cinnanomomea. At the end of the $20^{\text {th }}$ century within the section Caninae there were discovered 7 new species [28]. A special attention should be given to R. oxyodon from the section Cinnanomomea. As it is known, $R$. oxyodon is a cross-pollinated self-incompatible species which is characterized by a high changeability of morphological signs $[6,2,13,1]$. Our previous research showed its hybridogenic origin as a result of multiple reciprocal crossing between $R$. pendulina и $R$. majalis $[1,29]$. All of this points to intensive processes of speciation ongoing within the genus $[30,31]$.

According to ecological estimation, all the roses in Dagestan can be conventionally divided into two rows: xerophilous and mesophilous. The most prominent representative of the xerophilous trend is $R$. pimpinellifolia. The species of the xerophilous row occur in Intramountain and Foothill Dagestan. They grow mainly on stony substrates and raw soil with low level of humidification. Some scientists believe that the species of the xerophilous row are derivative, with a comparatively weak manifestation of form diversity [2].

The species of the mesophilous row develop on moistened, moderately developed or thick mountain meadow, mountain meadow forest and mountain forest soils. The most prominent representative is $R$. oxyodon which is characterized by the highly developed polymorphism. In sum, the species of the mesophilous row are florogenetically primary [2].

\section{Conclusion}

In sum, the taxonomic composition of the genus Rosa in Dagestan is not homogeneous. Within it there can be definitely singled out large species characterized by wide distribution and close concordance with the diagnoses of descriptions. These are the species $R$. canina L., R. corymbifera Borkh., R. pimpinellifolia L., R. oxyodon Boiss.. All of them possess 
high polymorphism and for these species there has been pointed out a great number of forms with different variations of signs. The second group is composed of the species with smaller natural habitats, and they are usually less changeable.

The genus Rosa in Dagestan is represented by the endemics and species demonstrating the connection between the flora of the region with the flora of the mediterranean, as well as with the asia minor caucasian flora and european flora. The core of endemism is represented by the species of the sections Caninae and Cinnanomomea.

Thus, the species composition of the wild roses in Dagestan requires a thorough revision and possibly replenishment.

\section{References}

1. B.A. Ramazanova, The structure and the resource potential of Dagestani populations and phylogenetic relationships of the sharp-toothed rose (2012)

2. E.S. Kolobov, Wild roses of Dagestan (1985)

3. S.V. Yuzepchuk, The flora of the USSR, 10 (1941)

4. S.G. Tamamshyan, Botanical Materials of the Herbarium of The Komarov Botanical Institute of the Russian Academy of Sciences, 11 (1949)

5. A.A. Grossheim, The flora of the Caucasus, 5 (1952)

6. V.G. Khrzhanovsky, Roses (1958)

7. A.I. Galushko, The wild roses of the middle part of the northern slope of the Greater Caucasus and their practical value (1959)

8. A.I. Galushko, The botanical materials of the Herbarium of The Komarov Botanical Institute of the Russian Academy of Science, 20 (1960)

9. A.I. Galushko, The flora of the North Caucasus, 2 (1980)

10. R.A. Murtazaliev, The summary of the flora of Dagesta, 1 (2009)

11. A.M. Ibrahimov, T.H. Talibov, A.V. Matsyara, Acta Biologica Sibirica, 4, 4 (2018)

12. M. Fougere-Danezan, S. Joly, A. Bruneau, X.-F. Gao, 1.-B. Zhang, Phylogeny and biogeography of wild roses with specific attention to poliploids, Annals of Botany, 115, 2 (2015)

13. I.O. Buzunova, R.V. Kamelin, Novitates Systematicae Plantarum non Vascularium, 6 (2004)

14. I.A. Shantser, G.Y. Klinkova, Bulletin of the Main Botanical Garden, 180 (2000)

15. I.A. Shantser, V.N. Voylokova, Botanical journal, 93 (2008)

16. I.A. Shantser, Bulletin of Moscow Society of Nature Testers. Section of biology, 103, $2(2001)$

17. I.A. Shantser, Bulletin of the Main Botanical Garden, 192 (2006)

18. I.A. Shantser, Hybridization, polymorphism and phylogenetic relationships of the species of the genus Rosa L. (2011)

19. K. De Cock, K. Vander Mijnsbrugge, P. Breyne, E. Van Bockstaele, J. Van Slycken, Annals of botany, 102, 5 (2008)

20. K. De Cock, Genetic defersity of wild roses (Rosa spp.) in Europe, with an in dept morphological study of Flemish populations (Gent University, 2008)

21. P. Bakker, B. Maes, R. Maskew, C. Stace, British\&Irish Botany, 1, 1 (2019)

22. R.A. Murtazaliev, Biological diversity of the Caucasus (2004)

23. A.A. Grossheim, Plant cover of the Caucasus (1948)

24. A.A. Fyodorov, Materials on the quaternary period of the USSR, 3 (1952)

25. A.A. Lepekhina, Botanical factors of the noospehere (2002)

26. R.V. Kamelin, Botanical journal, 91, 5 (2006)

27. A.A. Grossheim, Works of Botanical Institute of Azerbaijan Branch of the Academy of Sciences of the USSR, 1 (1935) 
28. Sh.A. Guseynov, Botanical journal, 74, 6 (1989)

29. I.A. Shantser, B.A. Abakarova (Ramazanova), Biogeography: methodology, regional and methodological aspects (2012)

30. M.J.M Smuiders, P. Arens, C.F.S Koning-Boucoiran, V.W. Gitonga, F.A. Krens, Rosa. Wild group revatives: genomic and breeding resources (2011)

31. V. Wisseman, C.M. Ritz, Botanical journal of the Linnean Society, 147, 3 (2005) 